\title{
ЭКСПРЕСС-ДИАГНОСТИКА
}

КРАСНУШНОЙ ИНФЕКЦИИ МЕТОДОМ ПРЯМОЙ ИММУНОФЛЮОРЕСЦЕНЦИИ С ИСПОЛЬЗОВАНИЕМ МОНОКЛОНАЛЬНЫХ АНТИТЕЛ
К БЕЛКУ Е1 ВИРУСА КРАСНУХИ

\author{
А.Н. Лисаков, Ф.Г. Нагиева, Е.П. Баркова, В.Г. Никулина, \\ Н.В. Юминова, Т.П. Антонова, А.Ю. Федотов
}

ФГБУ НИИ вакцин и сывороток им. И.И. Мечникова РАМН, Москва

\begin{abstract}
Резюме. Высокая заболеваемость краснухой в Российской Федерации и низкая регистрация синдрома врожденной краснухи по сравнению с расчетной требуют совершенствовать диагностику краснушной инфекции. В данной работе показана возможность раннего обнаружения вируса краснухи путем заражения чувствительных клеточных культур назофарингеальными смывами и детекции краснушного антигена с помощью высокоспецифичных моноклональных антител к основному структурному белку Е1 вируса краснухи прямым иммунофлюоресцентным методом. Постановка быстрого культурального метода позволяет в течение 5 часов с момента инфицирования чувствительных клеток Vero E6 или BНК21-F установить этиологический диагноз с высокой специфичностью.
\end{abstract}

Ключевые слова: быстрый культуральный метод, чувствительные клетки, вирус краснухи, моноклональные антитела, иммунофлюоресцентный метод.

\section{EXPRESS-DIAGNOSTIC OF RUBELLA INFECTION BY THE IMMUNOFLUORESCENT ASSAY USING MONOCLONAL ANTIBODIES TO PROTEIN E1 OF RUBELLA VIRUS}

Lisakov A.N., Nagieva F.G., Barkova E.P., Niculina V.G., Uminova N.V., Antonova T.P., Fedotov A.U.

Abstract. The high rubella incidence rate in the Russian Federation and the low registration level of the rubella congenital syndrome which is not reflect the epidemic situation requiring optimization of the rubella diagnostics. In the present study the possibility of early detection of rubella virus in case of inoculation of sensitive cell culture by the nasopharyngeal washouts with following detection of rubella antigen with highly specific monoclonal antibodies to the basic structural protein E1 of rubella virus using direct immunofluorescent method have been shown. Using of the rapid cell cultural method allows providing etiological diagnosis of high specificity within 5 hours after inoculation of virus to the sensitive cells Vero E6 or BHK-21-F. (Infekc. immun., 2012, vol. 2, N 4, p. 735-740)

Key words: rapid culture method, sensitive sells, rubella virus, monoclonal antibodies, immune-fluorescent assay.

\section{Введение}

Известно, что высокая заболеваемость краснухой в Российской Федерации и низкая регистрация синдрома врожденной краснухи по сравнению с расчетной свидетельствуют о несовершенстве диагностики краснушной инфекции $[4,5]$. Более того, клинический диагноз краснухи ненадежен и в половине случаев краснушная инфекция протекает субклинически и выявляется только при лабораторном обследовании [9]. поступила в редакцию 04.10.2012 принята к печати 15.10.2012

() Лисаков А.Н. и соавт., 2012
Адрес для переписки:

Нагиева Фирая Галиевна,

д.м.н., зав. лабораторией гибридных

клеточных культур отдела вирусологии

ФГБУ НИИВС им. И.И. Мечникова РАМН
115088, Москва, ул. 1-я Дубровская, 15, ФГБУ НИИВС им. И.И. Мечникова РАМН Тел.: (495) 674-76-45 (служебн.); 8916 272-79-01 (моб.).

E-mail: firaya77@gmail.com 
Вирус краснухи, помимо основных хорошо известных клинических синдромов (генерализованная лимфоаденопатия, нейросенсорная глухота, врожденная катаракта, врожденный порок сердца, тромбоцитопеническая пурпура, психическая неполноценность, физические уродства, различные формы артритов), способен вызывать панкреатит с последующим развитием диабета [11]. Наблюдают непрямую связь врожденной краснухи с развитием диабета 1 типа. Вирус индуцирует аутоиммунную реакцию против $\beta$-клеток островков Лангерганса с длительным преклиническим периодом и служит пусковым механизмом развития инсулинзависимого диабета у детей [10]. Было показано, что у пациентов с синдромом врожденной краснухи чаще встречается диабет 1 типа, чем у остальной популяции. Как оказалось, у больных диабетом с синдромом врожденной краснухи антиинсулиновые антитела присутствуют в $50-80 \%$ случаев, но в то же время подобные антитела обнаруживаются в $20 \%$ у детей с синдромом врожденной краснухи без диабета. Вместе с тем было показано, что вакцинация детей и подростков ассоциированными живыми вакцинами корьпаротит-краснуха (MMR) не может запустить аутоиммунные процессы в отличие от природной инфекции [13].

Нам представляется важным быстро и надежно устанавливать диагноз краснухи у детей и взрослых с подозрением на краснуху и включать переболевших краснухой в группу риска по инсулинзависимому диабету и аутоиммунным заболеваниям и периодически обследовать пациентов на данную патологию.

Цель нашей работы состоит в усовершенствовании методов лабораторной диагностики краснушной инфекции, используя для этой цели чувствительные клеточные культуры и моноклональные антитела к структурному гликопротеину Е1 вируса краснухи.

\section{Материалы и методы}

Клетки. Клеточная линия Vero E6 (почки эмбриона зеленых мартышек) получена из Института полиомиелита и вирусных энцефалитов им. М.П. Чумакова. Клеточная линия BHK-21-F (почки сирийского хомячка) восстановлена из криобанка клеточных культур НИИВС им. И.И. Мечникова.

Bupусы. Вакцинный штамм вируса краснухи Wistar RA27/3 восстановлен из вакцины Rudivax. Вакцинный штамм «Орлов» получен от д.м.н. И.Н. Лаврентьевой (Санкт-Петербург), лабораторный штамм «Judith» любезно предоставлен д-ром Б. Пустовойт (Германия).
Моноклональные антитела к структурному гликопротеину Е1 получены в нашей лаборатории с использованием гибридомной технологии [7].

Материалы от пациентов: смывы и соскобы со слизистой носоглотки в транспортной среде доставлены в лабораторию в замороженном состоянии из очагов краснушной инфекции, возникших в детских учреждениях г. Ивантеевки и г. Долгопрудного Московской области.

Изоляция вируса краснухи проводилась на монослое клеток Vero E6, выращенных в пластиковых культуральных флаконах емкостью 25 мл. До внесения биологического материала, монослой клеток дважды промывали фосфатным буфером, содержащим ионы $\mathrm{Ca}^{2+}$ и $\mathrm{Mg}^{2+}$. Адсорбция клинического материала на монослое клеток продолжалась в течение $1,5-2$ ч при $34^{\circ} \mathrm{C}$, затем в культуральный флакон вносили необходимое количество поддерживающей среды, содержащей $1 \%$ эмбриональной телячьей сыворотки (ЭТС, фирмы HyClone, США). Через 7-13 дней культивирования с однократной сменой среды, инфицированные клетки подвергали двукратному замораживанию с последующим оттаиванием и клеточную взвесь центрифугировали при 1000 об/мин в течение 10 мин, надосадок хранили при $-70^{\circ} \mathrm{C}$, а из осадка готовили препараты для индикации краснушных антигенов с использованием флюоресцирующих моноклональных антител.

Индикация краснушных антигенов проводилась прямым и непрямым методами иммунофлюоресценции по общепринятой схеме. Конъюгация мышиных моноклональных антител к структурному гликопротеину Е1 вируса краснухи проводили по методу [6].

Параллельно с заражением клеточной культуры клиническим материалом на предметном стекле готовили мазки, приготовленные из соскобов слизистой носоглотки пациентов. Препараты высушивали при комнатной температуре, фиксировали охлажденным этиловым спиртом и окрашивали моноклональными антителами, мечеными ФИТЦ. Реакцию учитывали с использованием флюоресцентного микроскопа «Optica» (Италия) при длине волны $510-550$ нм.

Реакцию гемагглютинации проводили c $0,4 \%$ эритроцитами одновневных цыплят, отмытых и суспендированных в физиологическом растворе.

Быстрый культуральный метод (БКМ) [1, 2, 14] в нашей модификации. Клеточную культуpy ВНК-21-F в концентрации 70 х $10^{3}$ клеток на лунку засевали в ростовой среде R PMI-1640 
с 5\% ЭТС и 40 мкг/мл гентамицина в объеме 1 мл на 24-луночные планшеты. Через 2448 ч культивирования после формирования сплошного монослоя клеток, монослой дважды промывали фосфатным буфером и в лунки вносили по 0,5 мл десятикратных разведений вируса краснухи (штамм «Орлов») в поддерживающей среде RPMI-1640 с 1\% ЭТС и культивировали при $34^{\circ} \mathrm{C}$. На каждое разведение вируса использовали по 3 лунки. Исходный титр вируса составлял 6,0 lg ТЦД $50 / 0,5$ мл. Начиная с 3-х часов и до 24-го часа культивирования проводили детекцию вирусинфицированных клеток с помощью моноклональных антител к белку Е1 вируса краснухи, конъюгированных с ФИТЦ в прямой реакции иммунофлюоресценции. Для этой цели планшеты замораживали-оттаивали, содержимое лунок переносили в центрифужные пробирки и клетки осаждали при 1500 об./мин в течение 5 мин. По окончании центрифугирования надосадочную жидкость удаляли, а из осадка готовили мазки. Для этого по 5 мкл клеточного осадка распределяли на предметных обезжиренных стеклах, высушивали при комнатной температуре, фиксировали дважды свежефильтрованным $3 \%$ параформальдегидом в течение 20 мин при комнатной температуре, затем промывали водопроводной водой, подсушивали при комнатной температуре и окрашивали ФИТЦ-конъюгатом, приготовленным на основе моноклональных антител к бел-

\section{ТАБЛИЦА 1. ИММУНОФЛЮОРЕСЦЕНТНЫЙ АНАЛИЗ КЛИНИЧЕСКОГО МАТЕРИАЛА ОТ ПАЦИЕНТОВ С ПОДОЗРЕНИЕМ НА КРАСНУШНУЮ ИНФЕКЦИЮ С ИСПОЛЬЗОВАНИЕМ ФЛЮОРЕСЦИРУЮЩИХ
МОНОКЛОНАЛЬНЫХ АНТИТЕЛ К БЕЛКУ Е1
ВИРУСА КРАСНУХИ}

\begin{tabular}{|c|c|c|c|c|}
\hline \multirow{2}{*}{$\begin{array}{l}\text { МКА изотипы } \\
\text { (РТГА }{ }^{*}\end{array}$} & \multicolumn{3}{|c|}{$\begin{array}{c}\text { Фамилия пациентов } \\
\text { и возраст }\end{array}$} & \multirow{2}{*}{$\begin{array}{c}\text { Контроль } \\
\text { клеток }\end{array}$} \\
\hline & $\begin{array}{c}\text { Ж-к } \\
2 \text { года }\end{array}$ & $\begin{array}{l}\text { 4-ис } \\
8 \text { лет }\end{array}$ & $\begin{array}{l}\text { Ш-ин } \\
9 \text { лет }\end{array}$ & \\
\hline $\begin{array}{c}\mathrm{Kx}-252, \mathrm{G} 2 \mathrm{~b} \\
(128)\end{array}$ & +++ & +++ & ++ & - \\
\hline $\begin{array}{c}\mathrm{Kx}-347, \mathrm{G} 2 \mathrm{a} \\
(16)\end{array}$ & ++ & +++ & ++ & - \\
\hline $\begin{array}{c}\mathrm{Kx}-183, \mathrm{G} 2 \mathrm{~b} \\
(1024)\end{array}$ & +++ & +++ & ++ & - \\
\hline $\begin{array}{c}\mathrm{Kx}-214, \mathrm{G} 1 \\
(16)\end{array}$ & ++ & ++ & + & - \\
\hline $\begin{array}{c}\mathrm{Kx}-187, \mathrm{G} 1 \\
(32)\end{array}$ & ++ & ++ & + & - \\
\hline
\end{tabular}

Примечание: здесь и далее * - обратная величина, «+»- наличие инфекционного фокуса, «-»- отсутствие инфекционного фокуса. ку Е1 вируса краснухи. Окрашивание проводили во влажной камере при $36,5^{\circ} \mathrm{C}$ в течение 40 мин. Реакцию учитывали на флюоресцентном микроскопе «Optica» под иммерсией при х1000 увеличении. Контролем служили неинфицированные клетки. В препаратах выявляли флюоресцирующие фокусы в различные временные интервалы.

\section{Результаты}

В работе были обследованы 36 клинических образцов от 11 пациентов с подозрением на краснуху. Материалы от пациентов собраны на 2-10 дни от начала появления сыпи. На 1-м этапе были исследованы материалы от 3-х пациентов (Ж-к, Ч-ис, Ш-ин). Соскобы из зева после стерилизующей фильтрации (миллипоровый фильтр с диаметром пор 0,22 мкм) вносили в монослой клеточной культуры Vero E6. Наблюдение за клеточными культурами проводили в течение 13 суток с однократой сменой среды на 4-е сутки культивирования. На первом пассажном уровне не было выявлено цитопатического действия внесенного материала на клеточных культурах Vero E6. Препараты, приготовленные из этих инфицированных клеточных культур, были исследованы методом прямой иммунофлюоресценции с использованием пяти моноклональных антител к гликопротеину Е1 вируса краснухи, конъюгированных с ФИТЦ (табл. 1).

Как видно из таблицы, все 5 серий флюоресцирующих иммуноглобулинов выявляют краснушный антиген в клеточных культурах, инфицированных материалами от пациентов c подозрением на краснушную инфекцию. В связи с этим в дальнейшем для выявления краснушных антигенов использовали две серии флюоресцирующих иммуноглобулинов, приготовленных на основе МКА Кх-252 и МКА Кх-183, обладающих более высокими титрами в РТГА.

В 9 образцах из 36 был выявлен краснушный антиген в цитоплазме инфицированных клеток.

Обследование инфицированных клеток после 2-го пассажа на клеточных культурах Vero Е6, выявило антиген вируса краснухи в 24 образцах от 11 пациентов. На 3-м пассажном уровне во всех исследованных образцах был выявлен цитопатогенный эффект, характерный для вируса краснухи. При этом необходимо отметить, что в 2-х образцах, принадлежащих пациентам 2 и 4 лет, наряду с дегенерацией клеток были обнаружены гигантские многоядерные клетки также характерные для вируса краснухи [3] (табл. 2). 
ТАБЛИЦА 2. ИНДИКАЦИЯ ГЛИКОПРОТЕИНА Е1 В КЛЕТОЧНЫХ КУЛЬТУРАХ VERO E6, ИНФИЦИРОВАННЫХ МАТЕРИАЛОМ ОТ ПАЦИЕНТОВ НА З-М ПАССАЖНОМ УРОВНЕ В ПРЯМОЙ ИММУНОФЛЮОРЕСЦЕНЦИИ И В РЕАКЦИИ ГЕМАГГЛЮТИНАЦИИ

\begin{tabular}{|c|c|c|c|c|}
\hline Пациенты & Возраст & $\begin{array}{c}\text { ФИТЦ-конъюгат } \\
\text { на основе МКА } \\
\text { Кx-252 (изотипа G2b) }\end{array}$ & $\begin{array}{c}\text { ФИТЦ-конъюгат } \\
\text { на основе МКА } \\
\text { Кx-183 (изотипа G2b) }\end{array}$ & $\begin{array}{c}\text { РГА* с 0,4\% } \\
\text { эритроцитами } \\
\text { цыплят }\end{array}$ \\
\hline Ан-ва** & 4 года & +++ & + & 64 \\
\hline E-OB & 5 лет & +++ & +++ & - \\
\hline В-як & 3 года & + & + & 128 \\
\hline Ж-к & 2 года & + & + & - \\
\hline $\mathrm{K}-\mathrm{OB}^{\star \star}$ & 2 года & +++ & +++ & 64 \\
\hline $\mathrm{H}-\mathrm{H}$ & 1 год & ++ & ++ & 128 \\
\hline$C-x$ & 10 лет & +++ & ++ & 32 \\
\hline П-як & 5 лет & + & + & 16 \\
\hline 4-ис & 8 лет & +++ & ++ & 8 \\
\hline Ш-ин & 9 лет & ++ & + & 8 \\
\hline Ш-ов & 9 лет & + & + & 128 \\
\hline «Орлов» & & ++++ & ++++ & 128 \\
\hline
\end{tabular}

Примечание: * обратные величины; ** гигантские многоядерные клетки.

Анализ полученных результатов, представленных в табл. 2, показывает, что у 11 пациентов со смывов из зева и соскоба со слизистых носоглотки выделен вирус краснухи, идентифицированный в прямом иммунофлюоресцентром анализе. При этом необходимо отметить, что оба иммунофлюоресцентных зонда выявляют основной антиген вируса краснухи - белок E1. Реакция гемагглютинации c $0,4 \%$ эритроцитами однодневных цыплят оказалась положительной только у 9 пациентов, причем титр РГА различался от минимальных (1:8) до максимальных значений (1:128). Необходимо отметить отсутствие корреляции между уровнем выявления инфекционных фокусов в прямой реакции иммунофлюоресценции и титрами РГА.

Представлялось важным, наряду с выделением вируса краснухи в чувствительной культуре клеток Vero E6, требующей несколько

\section{ТАБЛИЦА З. ВЫЯВЛЕНИЕ АНТИГЕНА ВИРУСА КРАСНУХИ В ИНФИЦИРОВАННОЙ КУЛЬТУРЕ КЛЕТОК В ЗАВИСИМОСТИ ОТ ЗАРАЖАЮЩЕЙ ДОЗЫ ВИРУСА}

\begin{tabular}{|c|c|c|c|c|c|}
\hline \multirow{2}{*}{$\begin{array}{c}\text { Время } \\
\text { инкубации } \\
\text { (в часах) }\end{array}$} & \multicolumn{4}{|c|}{ Инфицирующая доза в Ig IF } \\
\cline { 2 - 6 } & $\begin{array}{c}1 \\
\left(\mathbf{1 0}^{-6}\right)\end{array}$ & $\begin{array}{c}10,5 \text { мл } \\
\left(\mathbf{1 0}^{-5}\right)\end{array}$ & $\begin{array}{c}100 \\
\left(\mathbf{1 0}^{-4}\right)\end{array}$ & $\begin{array}{c}1000 \\
\left(\mathbf{1 0}^{-3}\right)\end{array}$ & $\begin{array}{c}10000 \\
\left(10^{-2}\right)\end{array}$ \\
\hline 3 & - & - & - & - & - \\
\hline 5 & - & + & + & + & + \\
\hline 24 & + & + & + & + & + \\
\hline
\end{tabular}

Примечание: «-» - отсутствие антигена вируса краснухи в инфицированных клетках; «+» - наличие антигена вируса краснухи в инфицированных клетках; в скобках десятикратные разведения вируссодержащей жидкости. слепых пассажей для создания цитопатического действия в клеточной культуре, оценить возможность непосредственной идентификации краснушных антигенов из эпителиальных клеток респираторного тракта у пациентов с подозрением на краснуху. С этой целью были приготовлены предметные стекла сфиксированными эпителиальными клетками носовых ходов ряда пациентов. Мазки были зафиксированы, окрашены иммунофлюоресцентными зондами и просмотрены в люминесцентном микроскопе. Интересно было отметить, что в мазках, содержащих эпителиальные клетки, обнаруживали антиген вируса краснухи. Этот опыт позволяет надеяться на возможность постановки диагноза краснушной инфекции непосредственно у постели больного.

В последние годы многие исследователи, разрабатывающие методы диагностики вирусных инфекций, обратили внимание на культуральный метод определения вируса в культурах чувствительных клеток. Данный метод был апробирован нами на модели вируса краснухи штамма «Орлов» и чувствительной к вирусам краснухи культуре клеток BНК-21-F. В табл. 3 представлены результаты эксперимента.

Как видно из данных, представленных в табл. 3, через 3 часа после инфицирования клеток ВНК-21-F ни в одной из заражающих доз вируса не было выявлено антигена вируса краснухи в реакции прямой иммунофлюоресценции. Через 5 часов с момента инфицирования при заражающей дозе вируса равной $10 \mathrm{lg}$ 
$\mathrm{IF}_{50 / 0,5}$ и больше в инфицированных клетках выявляли антиген вируса краснухи. К 24 часам с момента инфицирования степень специфической флюореценции краснушного антигена в клетках увеличивалась при всех заражающих дозах; при этом цитопатическое действие вируса на клеточных культурах еще не проявлялось. На рисунке (см. IІ обложку) представлены фотографии результатов эксперимента.

\section{Обсуждение}

В данной работе были представлены результаты экспериментов по усовершенствованию методов экспресс-диагностики краснушной инфекции с использованием чувствительных к краснухе клеточных культур и индикации краснушных антигенов с помощью флюоресцирующих моноклональных антител к структурному белку Е1 вируса краснухи. Материалом для исследования служили назофарингеальные клинические образцы от 11 пациентов с подозрением на краснуху. Как правило, для изоляции вируса краснухи из клинического материала на чувствительных клеточных культурах требуется две недели и нередко несколько слепых пассажей, пока в клеточных культурах не накапливается вирус в количествах, достаточных для проявления цитопатического действия вируса. При этом надо помнить, что цитопатическое действие, вызванное вирусом краснухи должно быть подтверждено с помощью интерференционных тестов с контрольным вирусом. С целью эффективного обнаружения инфицированности клеточных культур вирусом краснухи в отсутствии цитопатического действия вируса, был проведен иммунофлюоресцентный анализ клеточных культур после 1-го пассажа. В отсутствии цитопатического действия вируса на клеточных культурах с помощью пяти серий флюоресцентных зондов был проведен иммунофлюоресцентный анализ и установлено наличие в клеточных культурах, зараженных клиническими образцами от 3-х пациентов, гликопротеина Е1 вируса краснухи. Этот метод был применен при изоляции вируса краснухи из 36 назофарингеальных образцов от 11 пациентов и в 100\% случаев получен положительный результат. Такой результат обусловлен тем, что вирус краснухи длительно выделяется во внешнюю среду за 13 дней до появления сыпи и в течение 3 недель после высыпания [10]. Иммунофлюоресцентный анализ был использован нами также для оценки наличия вирусного антигена непосредственно в мазках из назофарингеальных клинических образцов. В некоторых мазках, содержащих эпителиальные клетки из слизистой носоглотки, в прямом иммунофлюоресцентном анализе был выявлен краснушный антиген. При этом необходимо отметить, что положительный результат в данном случае напрямую связан с качеством забора клинического материала. В связи с этим оптимальным, на наш взгляд, вариантом экспрессдиагностики краснушной инфекции является широко распространенный быстрый культуральный метод. Быстрый культуральный метод позволяет установить диагноз краснухи в течение первых 5 часов с момента инфицирования чувствительных клеток Vero E6 или ВНK-21-F.

\section{Список литературы}

1. Быстрый культуральный метод диагностики герпесвирусных инфекций. Методические рекомендации № 02.030-08. - М.: Роспотребнадзор, 2008. - $20 \mathrm{c}$.

2. Васильев А.Н., Федорова Н.Е., Климова Р.Р., Адиева А.А. Совершенствование диагностики герпес-вирусных инфекций // Клин. лаб. диагностика. - 2012. - № 6. - С. 52-55.

3. Вакциноуправляемые респираторные вирусные инфекции (грипп, корь, краснуха, эпидемический паротит) / Под. ред. И.Г. Дроздова. - Новосибирск: Изд-во Типография № 1, 2008. - 210 с.

4. Говорухина М.В., Тихонова Н.Г. Роль лабораторного подтверждения кори и краснухи в период элиминации кори // Эпидемиология и вакцинопрофилактика - 2006. - Т. 1, № 26. C. 17-20.

5. Зверев В.В., Юминова Н.В. Проблемы кори, краснухи и эпидемического паротита в Росийской федерации // Вопросы вирусологии. - 2004. Т. 49, № 3. - С. 8-11.

6. Лимфоциты. Методы / Под ред. Дж. Клауса. М.: Мир, 1990. - 394 с.

7. Нагиева Ф.Г., Никулина В.Г., Баркова Е.П., Зубков А.В., Кузьмина А.С., Десятскова Р.Г., Ткаченко А.В., Юнасова Т.Н. Моноклональные антитела к гликопротеину Е1 вируса краснухи // ЖМЭИ. 2011. - № 1. - С. 61-67.

8. Поляков В.Е., Смирнова Т.Н., Казакова С.И., Авдеева Г.Ф., Цвылева М.В., Иванова И.А. Актуальные проблемы краснушной инфекции // Педиатрия. - 2004. - № 1. - С. 84-90.

9. Чаплыгина Н.М., Кицак В.Я. Современные методы диагностики врожденной вирусной инфекции // Росс. вестн. перинатологии. - 1996. № 1. - C. 31-34.

10. Alba A., Planas R., Verdaguer J., Vives M. Viral infections and autoimmune diabetes // Immunologia. 2005. - Vol. 1, N 24. - P. 33-43. 
11. Burgess M.A., Forrest J.M. Congenital rubella and diabetes mellitus // Diabetologia. - 2009. - Vol. 52, N 2. - P. 369-370.

12. Castillo-Solorzano C., Carrasco P., Tambini G., Reef S., Brana M., de Quadros C.A. New horizons in the control of rubella and prevention of congenital rubella syndrome in the Americas // J. Infect. Dis. 2003. - Vol. 187, Suppl. 1. - P. S146-152.

13. Lindberg B., Ahlfors K., Carlsson A., Ericsson U.B., Landin-Olsson M., Lernmark A., Ludvigsson J., Sund- kvist G., Ivarsson S.A. Previous exposure to measles, mumps, and rubella - but not vaccination during adolescence - correlates to the prevalence of pancreatic and thyroid autoantibodies // Pediatrics. - 1999. Vol. 104, N 1. - P. 1-5.

14. Rein S., Ballesteros F., Mari M., Munar M. Evaluation of different continuous cell lines in the isolation of mumps virus by the shell vial method from clinical samples // J. Clin. Pathol. - 2001. - Vol. 54. P. 924-926. 

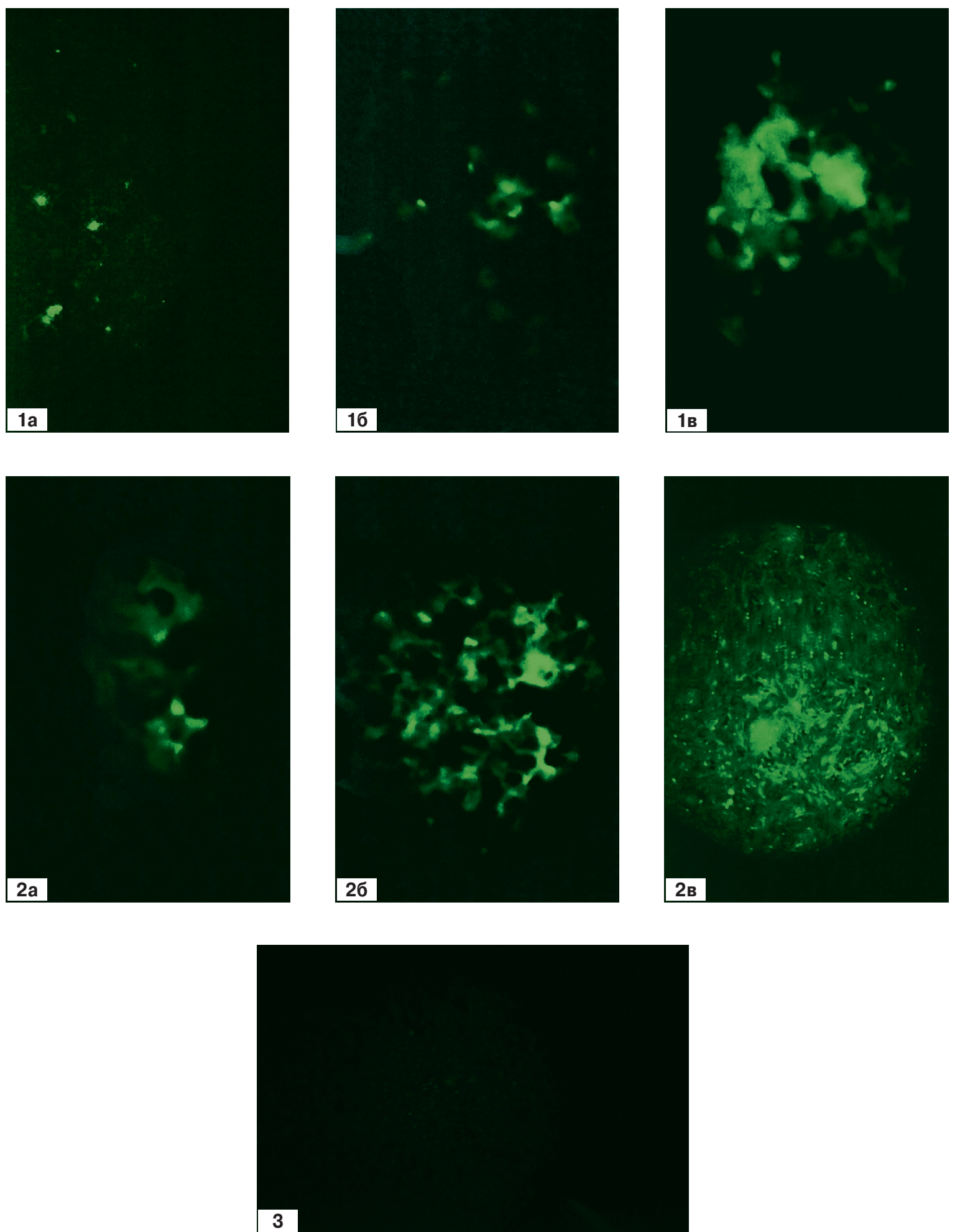

Рисунок. Выявление вируса краснухи быстрым культуральным методом в клеточной культуре BHK-21-F, инфицированной различными дозами вируса краснухи штамма «Орлов»

1 и и $2 a-10$ доз вируса через 5 и 24 часа;

$1 б$ и $2 б-100$ доз вируса через 5 и 24 часа;

1в и 2в - 1000 доз вируса через 5 и 24 часа;

3 - контроль неинфицированных клеток. 